\title{
NIH wasted millions on computers
}

\section{Washington}

IN 1988, computer officers at the U.S. National Institutes of Health (NIH) contracted with IBM for a major computer system with a potential value over ten years of $\$ 806$ million that was meant to meet all of the institutes' computing needs. Unfortunately, those responsible for deciding to go with an IBM mainframe system failed to ask NIH scientists what kind of computing systems they wanted. Had they done so, according to a report from the US General Accounting Office, they would have discovered that many of the scientists favoured plain PCs and have no need for the "total system" for which $\mathrm{NIH}$ issued a contract.

The GAO report, which current NIH officials have not contradicted, records a priceless example of bureaucracy run amok. Although the NIH have various computer advisory committees, the bureaucrats who chose the IMB mainframe system failed to consult any of them. Nor, according to the GAO, did they interview scientists because "they did not believe it was worthwhile to spend time surveying scientists," in part apparently because of a survey 20 years previously that "produced unmanageable results".

The total system NIH now has not only has excess capacity, but also includes one full-sized computer dedicated to backup and related needs. However, GAO notes that NIH mainframes (leased in earlier years) are connected in such a manner that one backs up another during a system failure. "Consequently, NIH mainframes virtually never fail and have been so reliable that NIH no longer keeps mainframe failure data."

As to the scientists, who were heard from through an advisory body 4 months after the 1988 contract was signed, the availability of new software for personal computers rendered the need for mainframes for most scientific research outmoded. Besides, they said, the user charges for the multi-million dollar IBM system were too high.

So, while most researchers are happy with their PCs, NIH has wasted millions on a system is apparently does not need. GAO recommends that in the future NIH should solicit data on scientists' needs before buying them equipment they do not need and cannot afford. The current NIH leadership admits that is pretty good advice.

Barbara J. Culliton

\section{Green scheme to open Asian markets}

\section{Washington}

HoPING to open markets for US environmental companies in Asia, President George Bush announced plans last week to use the resources of 18 US agencies to match US experts and technology with Asian environmental problems. The agencies will sponsor trade fairs in Asia, travel to US environmental trade shows for Asian buyers, and environmental training institute in a Asian country to be named later. The US Agency for International Development will also start a biodiversty programme that will sponsor collaborative research on sustainable agriculture and conservation of genetic resources in Asia. Speaking in Singapore on 4 January, Bush promised that the initiative, known as the United States-Asia Environmental Partnership, "will be good for Asia's environment and good for American jobs." Environmental groups are concerned that the balance favors the latter. "It's mostly just the [Administration] agenda of increasing business opportunities," says Lawrence Williams, director of international programmes at the Sierra Club.

Chris Anderson

\section{HUGO opposes}

\section{Venter}

\section{London}

The Human Genome Organisation (HUGO) is contacting government officials and patent offices around the world, after deciding to oppose the attempt by Craig Venter, a researcher at the US National Institutes of Health, to patent more than
300 cDNA sequences. HUGO president Sir Walter Bodmer says that patenting cDNA sequences - fragments of genes whose function is not yet known - could lead to research groups working "in isolation and inadvertent competition, seriously slowing down research". HUGO is the second body representing genome researchers to oppose Venter's move, following the lead of the American Society of Human Genetics.

Nevertheless, NIH officials who bear responsibility for filing a patent application (Venter himself does not decide) are determined to press ahead even though they will set off what has been called "an enormous cDNA arms race (see Nature, 353:485). Critics of the patent application have argued that the filing is an abuse of the patent system, but NIH attorneys find the allaegation irrelevant. Their concern is to convince the patent office that the cDNA sequences Venter has found have some utility (which is required before a patent can be granted) even though neither Venter nor anyone else yet knows exactly what the sequences mean.

Peter Aldhous

\section{Institute for best and brightest}

\section{New Delhi}

Maharashtra state will soon set up an institute of advanced studies for exceptionally talented students. The new institute will be located in Bombay and offer an integrated five year course leading to a master's degree in basic sciences, with opportunities for students to work with leading scientists in national laboratories for their doctoral programmes.

The institute will admit 400 students each year. In contrast to existing government funded educational institutions that reserve places for students from economically weaker sections of society, the proposed institute will enrol students exclusively on merit on the basis of state-wide competitive examinations.

Proposals to set up institutes of excellence for really talented students were made three years ago by the scientific advisory committee to the prime minister and the Indian National Science Academy. Now that Maharashtra has taken the lead, other states are expected to follow suit.

K.S. Jayaraman

\section{Training for \\ Egyptian scientists}

\section{Cairo}

A collaborative project between the University of California at Davis and the Veterinary Serum and Vaccine Research Institute here is the latest effort by the U.S. Agency for International Development (AID) to staunch the brain drain of African scientists. The agency has awarded $\$ 1.9$ million for a research project on a vaccine for rinderpest (from the German for cattle disease) that is meant to help in the transfer of recombinant DNA technology from the United States to Egypt.

During the next four years, 11 Egyptian scientists will study at Davis in the laboratory of Ethiopian virologist Tilahun Yilma who is director of the collaborative project. There they will learn how to make recombinant vaccine for rinderpest, which kills hundreds of thousands of cattle in Africa every year. Meanwhile, AID funds will be put to use building a modern molecular biology laboratory here which, it is hoped, will serve as a lure to attract the Egyptian scientists back home after training in California.

Jane Ferrell-Stevens 